\title{
Baikal endemic sponges in the system of ecological monitoring
}

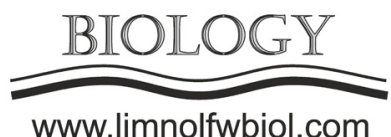

\author{
Maikova O.O.*, Kravtsova L.S., Khanaev I.V. \\ Limnological Institute, Siberian Branch of the Russian Academy of Sciences, Ulan-Batorskaya Str., 3, Irkutsk, 664033, Russia
}

\begin{abstract}
Within the framework of the monitoring of the Baikal endemic sponge fauna, which was started in 2015, we organized field observations. This study is aimed to investigate the dynamics of the disease incidence in sponges and the rate of their degradation/regeneration in the natural environment within a limited space. The observations of the tagged sponges having different shapes were carried out using the photo and video method. Thus, from 2016 to 2018, there was a deterioration dynamics in the state of most control sponges. From 2018 to 2019, the state of some sponges improved owing to the regeneration of the affected areas of the body. In this study, we revealed that Baikal sponges with encrusted and globulous shapes could recover very quickly owing to the regeneration of the affected areas and the rapid growth of the body. After almost complete degradation of the body in the encrusted sponge, the fragments remain, which can subsequently grow as individual specimens. Similar observations are currently being conducted throughout Lake Baikal.
\end{abstract}

Keywords: sponge mortality, tagged (marked) sponges

\section{Introduction}

Sponges play a significant role in the ecosystem of any water body. They serve as the habitat for many organisms and are important in benthic-pelagic interaction due to their impressive filtration activity. Sponges provide extraordinary flows of matter and energy; at sites of their accumulation, there is a large species diversity of organisms (Maldonado et al., 2015). They process a solid substrate, accelerating bioerosion, and are involved in the processing of organic compounds of primary production through microbial symbionts (Bell, 2008). Currently, there are 7 families, 47 genera and 236 freshwater species in the World sponge fauna (Manconi and Pronzato, 2019). In Lake Baikal, 15 species of the endemic family Lubomirskiidae and 5 species of the cosmopolitan species Spongillidae have been described (Efremova, 2001; 2004; Itskovich et al., 2017; Manconi and Pronzato, 2019; Bukshuk and Maikova, 2020). Baikal endemic sponges are an example in the formation of the bouquet of closely related but morphologically different species that are adapted to the unique conditions of a deep-water lake. According to the visual observations of I.V. Khanaev and some publications (Kozhov, 1972; Masuda, 2009; Efremova, 2001; 2004; Bukshuk and Timoshkin, 2013), sponges are adapted to inhabit a wide range of depths, from 1.5 to $1540 \mathrm{~m}$. Although the species composition of sponges in Lake Baikal is small in comparison with other representatives of zoobenthos, they are a constant and very significant component of bottom communities (Kozhov et al., 1969). The bulk of their abundance and species diversity is at depths of 3-40 m (Efremova, 2004; Masuda, 2009). This depth range concentrates the main species diversity of many benthic organisms, and this zone is currently experiencing the greatest changes indicating an increasing anthropogenic load (Kravtsova et al., 2012; 2014; Kobanova et al., 2016; Timoshkin et al., 2016). Attached sponges are very stressed when environmental conditions change. Stress can affect the physiological state of sponges, which entails the loss of control over microbiome and, consequently, the development of diseases (Pita et al., 2018).

Information about the disease of marine sponges first appeared approximately 100 years ago. At that time, losses of commercial sponges due to the diseases reached 95\% in some areas (Smith, 1941). The first data on diseased Baikal sponges were published in 2011 (Bormotov, 2011). At present, diseased sponges are found in all three basins of Lake Baikal (Timoshkin et al., 2016; Khanaev et al., 2018). These data on the disease of freshwater sponges were the first in the world literature; though in marine ecosystems this problem has been already existing for decades.

In 2015, comprehensive monitoring of the state of sponge fauna in Lake Baikal was organized. Along the transects laid in all three Baikal basins, the projective cover of the bottom with healthy and diseased sponges were measured and their species diversity and state were evaluated. We used the underwater photo and 
video method that is widely used to monitor the state of attached animals. Additionally, we used the tagging of single (separate) sponges, which is also widely used to study corals and sponges, including monitoring the rate of the disease progression (Hill and Wilkinson, 2004; Sweet et al., 2015; Precht et al., 2016). In 2015, based on the library materials, freeze-frame data and videos of the Baikal bottom, the number of the affected sponges ranged from 2.4 to $19.1 \%$. The proportion of the affected branched sponges was higher (from $8.5 \%$ to $63.3 \%$ ) than that of encrusting ones (from $0.5 \%$ to 17.9\%). Sponges are diseased throughout the lake; however, in Listvennichny Bay, the anthropogenic factor significantly aggravates the situation. Here, the lesion of branched sponges is $100 \%$, encrusted sponges - up to $50 \%$ and globulous sponges - 38\% (Khanaev et al., 2018).

In addition to the transects, the monitoring system of the state of the Baikal sponge fauna includes field observations at the site located in Bolshiye Koty Bay opposite Varnachka Valley (Fig. 1). This study aims to investigate the dynamics of disease incidence in sponges and the rate of their degradation/regeneration in the natural environment within a limited space.

\section{Materials and methods}

A natural site of the sponge state observations was organized on 4 June 2016 opposite Varnachka Valley, $170 \mathrm{~m}$ from the water's edge (the edge coordinates

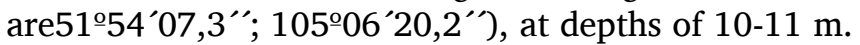
White stones indicated the boundaries of the site. The area of the site is approximately $6 \mathrm{~m}^{2}$ (Fig. 1). For the observation site, we chose a section of the bottom in Baikal having an outcrop ridge separately rising from the main slope, with minor affected sponges of different body shapes: globulous, encrusted and branched.

The projective cover of the bottom with sponges (the percentage of sponge cover relative to the total area of the site) was calculated using the ImageJ programme by photographs taken in opposite angles on the day of the site organization.

For regular video filming, seven specimens were randomly selected and tagged within the boundaries of the site: two globulous, three encrusted and two branched sponges. Tags were made of rubber and had a round form with a diameter of $20 \mathrm{~mm}$; they were attached to the sponges by thin stainless steel nails. Each tagged sponge had a number (Table 1). To assess the progression of the disease lesion, the tagged sponges were monitored in the field using photographs. SCUBA divers took photographs every year in June.

The degree of lesion or degradation of the sponge body was assessed visually by photographs using scoring system (Easson et al., 2013; Maldonado et al., 2015): 0 - no signs of lesion, 1 - start of lesion, point lesions of the body (lesion occupies approximately up to $20 \%$ of the body), 2 - continued lesions (less than $50 \%$ of the body), 3 - severe lesion (more than $50 \%$ of the body); 4 - degradation of the specimen (to its complete or partial disappearance).

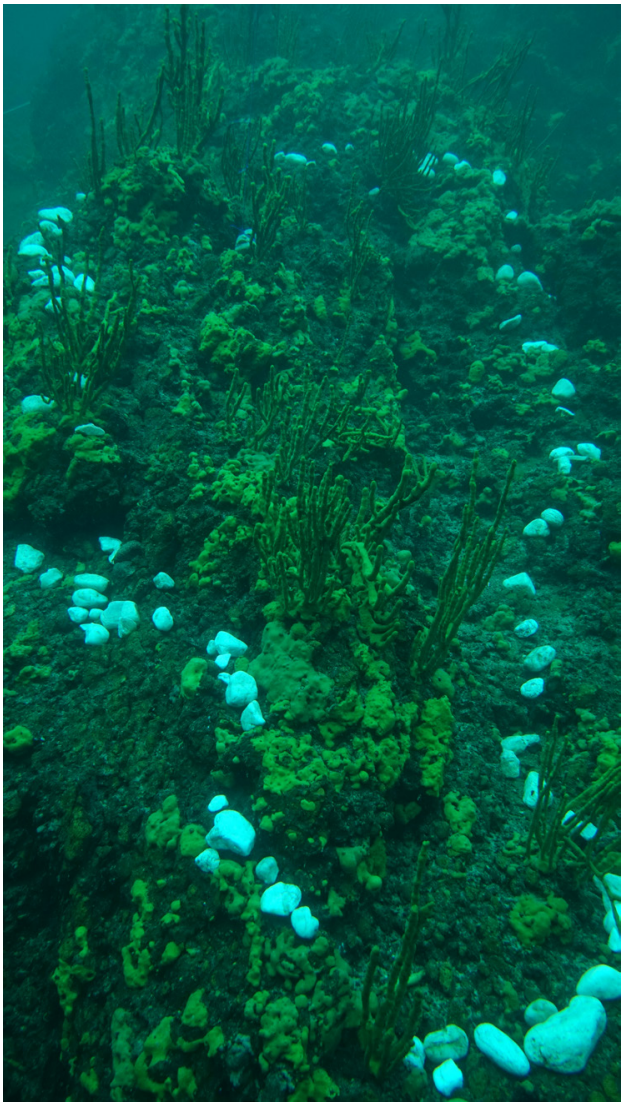

Fig. 1. The site with sponges; white stones indicate the boundaries.

\section{Results and discussion}

On 4 June 2016, the projective cover of the bottom with sponges of all shapes was 26-36 \% (Fig. 1).

Table 1 shows the list of tagged sponges with a description of the lesion development (in points). Throughout the entire observation period (from 2016 to 2019), only one branched sponge under the number VB-2 lacked the disease or any lesion. Other branched sponge, VB-1, had stable point lesion of the body (1 point). Over four years, the lesion degree of the body surface in this sponge did not exceed 20\%, which probably indicates some stability and resistance to disease.

Table 1. Description of the lesion degrees in the tagged sponges using a scoring system

\begin{tabular}{|c|c|c|c|c|}
\hline \multirow{2}{*}{$\begin{array}{c}\text { Number and body } \\
\text { shape of a specimen }\end{array}$} & \multicolumn{4}{|c|}{ State of a specimen } \\
\cline { 2 - 5 } & in 2016 & in 2017 & in 2018 & in 2019 \\
\hline VB-1, branched & 1 & 1 & 1 & 1 \\
VB-2, branched & 0 & 0 & 0 & 0 \\
VG-1, globulous & 0 & 1 & 2 & 1 \\
VG-2, globulous & 0 & 0 & 1 & 0 \\
VE-1, encrusting & 0 & 2 & 4 & 4 \\
VE-2, encrusting & 0 & 0 & 1 & 0 \\
VE-3, encrusting & 0 & 0 & 1 & 0 \\
\hline
\end{tabular}


In three sponges (globulous VG-2 as well as encrusted VE-2 and VE-3) point lesions of the body (1 point) appeared after two years (in 2018), but already in 2019, there was tissue regeneration of the affected areas. Similar processes were also observed in another globulous sponge, VG-1. The first point lesions of the body surface (up to 20\%) in this sponge were recorded in 2017, and in 2018, lesions affected $50 \%$ of the body surface, but already in 2019 , the affected areas reduced and were again up to $20 \%$ (Fig. 2). In other words, the rate of the relative recovery of affected areas owing to tissue regeneration and growth of encrusted and globulous species is sufficiently high. In 2019, we observed not only partial regeneration of the affected areas but also covering the tag with a sponge (overgrowing of the tag with a sponge).

Figure 3 shows the encrusted sponge VE-1. This sponge had no lesions of the body when the observations were organized (in 2016); in 2017, a significant part of the body was degraded (ca. 50\%) compared to the initial state. In 2018, the sponge degraded almost completely; only small separate fragments of the body remained. It is possible that in the future each of them will be able to grow as an independent specimen. Therefore, by 31 July 2019, among the tagged sponges at the observation site, one specimen (VE-1) degradated.

\section{Conclusions}

In general, at the beginning of the observations (June 2016), we ascertained a sufficiently good state of control sponges (among seven control sponges, only one had initial signs of the lesion) at the observation site. A year later, in June 2017, we observed a slight deterioration in the general state associated with the addition of one more sponge having initial signs of the lesion (VG-1) and worsening of the state of the encrusted sponge (VE-1). After another year, in June 2018, the deterioration in the state continued: in five sponges, the lesion degree worsened (in globulous and encrusted sponges), and in two branched sponges, the lesion degree did not change. In 2019, we observed a slight improvement in the state of control sponges compared to 2018: four sponges (two encrusted and two globulous) had changes in the lesion degree resulted from the regeneration of some affected areas of the body; in two branched sponges, the lesion degree did not change. Of course, we cannot assess the state of the entire sponge fauna in the lake by the state dynamics of the studied sponges. This requires similar observations throughout Lake Baikal, at sites with the highest abundance of sponges.

Long-term field observations of the state of sponge fauna have revealed that sponges of any shape inhabiting Lake Baikal can be affected. Regardless of the lesion degree, sponges are capable of regenerating or degrading to complete disappearance. Moreover, fragments of the body remaining after degradation of encrusted sponge can subsequently grow as independent specimens.

The results of the observations of separate Baikal sponge specimens are the first in the system of monitoring that we started in 2015. There are still tagged sponges in other areas of the lake. These studies are being continued and will more completely elucidate the dynamics of changes in the state of the Baikal sponge fauna.

\section{Acknowledgements}

This study was performed within the framework of the State Tasks Nos. 0345-2019-0002 and 03452019-0004 and supported by the RFBR grant No. 19-04-00787A.

\section{References}

Bell J.J. 2008. The functional roles of marine sponges. Estuarine, Coastal and Shelf Science 79: 341-53. DOI: 10.1016/j.ecss.2008.05.002

Bormotov A.E. 2011.What happened to Baikal sponges? Science First Hand 5: 20-23.

Bukshuk N.A., Maikova O.O. 2020. A new species of Baikal endemic sponges (Porifera, Demospongiae, Spongillida, Lubomirskiidae). ZooKeys 906: 113-130. DOI: 10.3897/ zookeys.906.39534

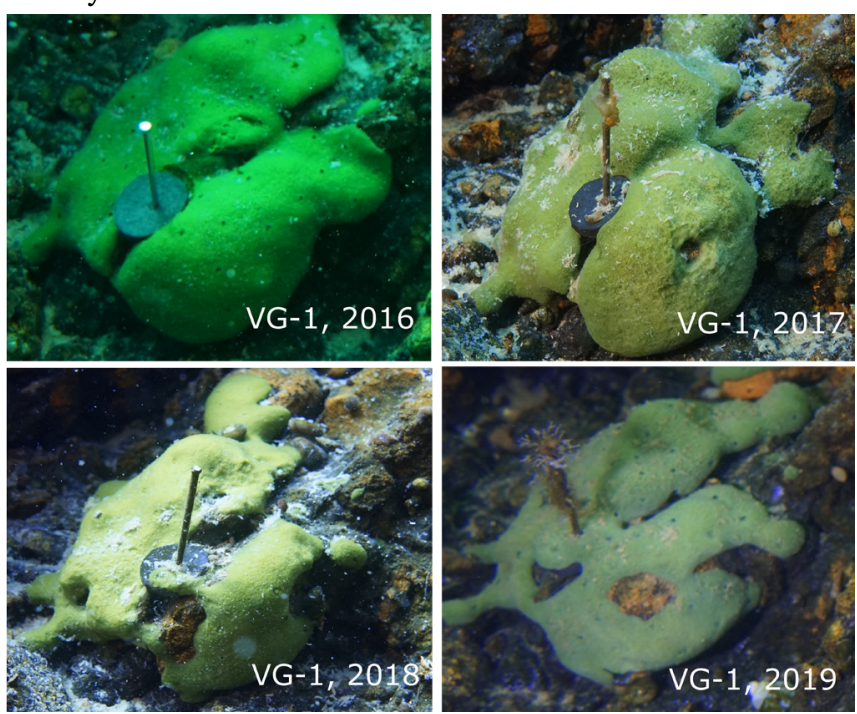

Fig. 2. Development dynamics of the lesion degrees over the years in the globulous sponge VG-1.
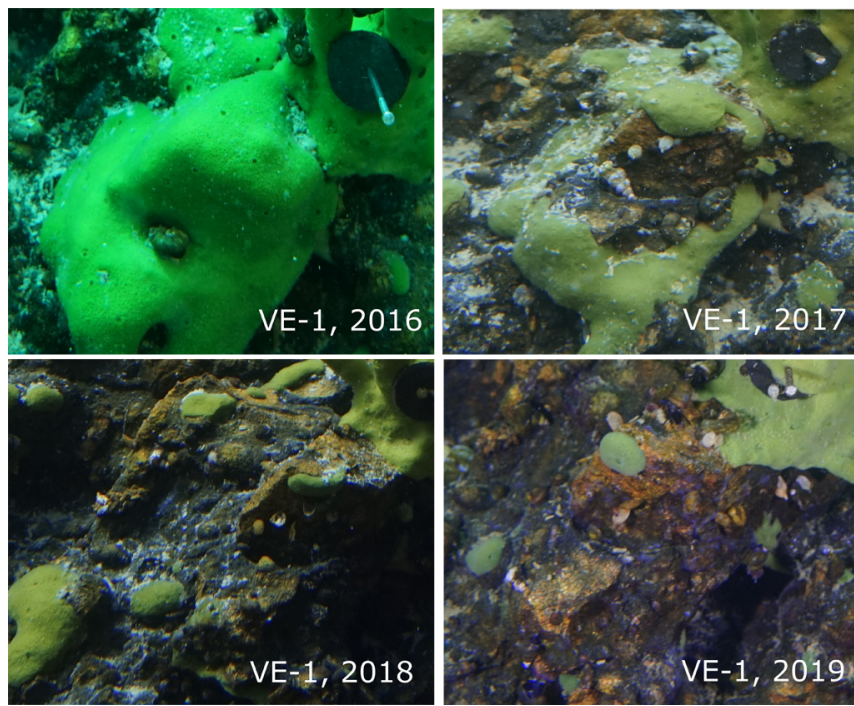

Fig. 3. Development dynamics of the lesion stages over the years in the encrusted sponge VE-1. 
Bukshuk N.A., Timoshkin O.A. 2013. Some features of Baikalospongia intermedia (Spongia: Lubomirskiidae) morphology and vertical distribution in deep-water zone of Lake Baikal. Izvestiya Irkutskogo Gosudarstvennogo Universiteta. Seriya "Biologiya. Ekologiya" [The bulletin of Irkutsk State University. Series "Biology. Ecology"] 6: 128-131. (in Russian)

Easson C.G., Slattery M., Momm H.G. et al. 2013. Exploring individual - to population-level impacts of disease on coral reef sponges: using spatial analysis to assess the fate, dynamics, and transmission of Aplysina Red Band Syndrome (ARBS). PlosOne 8. DOI: 10.1371/journal.pone.0079976

Efremova S.M. 2001. Sponges (Porifera). In: Timoshkin O.A. (Ed.), Opredelitel' presnovodnykh bespozvonochnykh Rossii i sopredel'nykh territoriy. Novosibirsk, pp. 179-192. (in Russian)

Efremova S.M. 2004. Novel genus and novel species of the Lubomirskiidae Rezvoj, 1936 sponge family. In: Timoshkin O.A. (Ed.), Opredelitel' presnovodnykh bespozvonochnykh Rossii i sopredel'nykh territoriy. Novosibirsk, pp. 1261-1278. (in Russian)

Hill J., Wilkinson C. 2004. Methods for ecological monitoring of coral reefs: a resource for managers. Townsville: Australian Institute of Marine Science.

Itskovich V., Kaluzhnaya O., Veynberg Y. et al. 2017. Endemic Lake Baikal sponges from deep water. 2: study of the taxonomy and distribution of deep-water sponges of Lake Baikal. Zootaxa 4236: 335-342. DOI: 10.11646/ zootaxa.4236.2.8

Khanaev I.V., Kravtsova L.S., Maikova O.O. et al. 2018. Current state of the sponge fauna (Porifera: Lubomirskiidae) of Lake Baikal: sponge disease and the problem of conservation of diversity. Journal of Great Lakes Research 44: 77-85. DOI: 10.1016/j.jglr.2017.10.004G.I., Takhteev V.V., Rusanovskaya O.O. et al. 2016. Lake Baikal ecosystem faces the threat of eutrophication. International Journal of Ecology 2016. DOI:10.1155/2016/6058082

Kozhov M.M. 1969. Benthos of the southeast coast of Lake Baikal. In: Kozhov M.M., Izhboldina L.A., Kaplina G.S. et al. (Eds.), Biologicheskaya produktivnost' vodoyemov Sibiri. Doklady pervogo soveshchaniya po biologicheskoy produktivnosti vodoyemov Sibiri. Irkutsk, pp. 29-37. (in Russian)
Kozhov M.M. 1972. Ocherki po baykalovedeniyu. Irkutsk: Ogiz. (in Russian)

Kravtsova L.S., Izhboldina L.A., Khanaev I.V. et al. 2012. Disturbances of the vertical zoning of green algae in the coastal part of the Listvennichnyi Bay of Lake Baikal. Doklady Biological Sciences 448: 227-229. DOI: 10.1134/ S0012496612060026

Kravtsova L.S., Izhboldina L.A., Khanaev I.V. et al. 2014. Near-shore benthic blooms of filamentous green algae in Lake Baikal. Journal of Great Lakes Research 40: 441-448. DOI: 10.1016/j.jglr.2014.02.019

Maldonado M., Aguilar R., Bannister R. et al. 2015. Sponge grounds as key marine habitats: a synthetic review of types, structure, functional roles and conservation concerns. In: Rossi S., Bramanti L., Gori A. et al. (Eds.), Marine animal forests. Cham, pp. 145-183. DOI: 10.1007/978-3-319-21012-4

Manconi R., Pronzato R. 2019. Phylum Porifera. In: Rogers D.C., Thorp J. (Eds.), Keys to palaearctic fauna: Thorp and Covich's freshwater invertebrates, 4th edition. Amsterdam, pp. 45-87.

Masuda Y. 2009. Studies on the taxonomy and distribution of freshwater sponges in Lake Baikal. In: Müller W.E.G., Grachev M.A. (Eds.), Biosilica in evolution, morphogenesis, and nanobiotechnology. Berlin Heidelberg, pp. 81-110. DOI: 10.1007/978-3-540-88552-8_4

Pita L., Rix L., Slaby B.M. et al. 2018. The sponge holobiont in a changing ocean: from microbes to ecosystems. Microbiome 6. DOI: 10.1186/s40168-018-0428-1

Precht W.F., Gintert B.E., Robbart M.L. et al. 2016. Unprecedented disease-related coral mortality in Southeastern Florida. Scientific Reports 6: 1-11. DOI: 10.1038/srep31374

Smith F.G.W. 1941. Sponge disease in British Honduras, and its transmission by water currents. Ecology 22: 415-421.

Sweet M., Bulling M., Cerrano C. 2015. A novel sponge disease caused by a consortium of microorganisms. Coral Reefs 34: 871-883. DOI: 10.1007/s00338-015-1284-0

Timoshkin O.A., Samsonov D.P., Yamamuro M. et al. 2016. Rapid ecological change in the coastal zone of Lake Baikal (East Siberia): is the site of the world's greatest freshwater biodiversity in danger? Journal of Great Lakes Research 42: 487-497. DOI: 10.1016/j.jglr.2016.02.011 